\section{artelogie}

\section{Artelogie}

Recherche sur les arts, le patrimoine et la littérature de I'Amérique latine

17 | 2021

Transformaciones en Cuba contemporánea: cultura y sociedad

\title{
Rumberas matanceras. Un canto a la memoria, Roxana M. Coz Téstar Miami, Estados Unidos. Unos \& Otros Ediciones, 2020. 154 páginas.
}

\section{Rosa Marquetti Torres}

\section{CpenEdition}

\section{Journals}

Edición electrónica

URL: https://journals.openedition.org/artelogie/9698

DOI: $10.4000 /$ artelogie.9698

ISSN: 2115-6395

Editor

Association ESCAL

Referencia electrónica

Rosa Marquetti Torres, «Rumberas matanceras. Un canto a la memoria, Roxana M. Coz Téstar Miami, Estados Unidos. Unos \& Otros Ediciones, 2020. 154 páginas. », Artelogie [En línea], 17 | 2021,

Publicado el 07 septiembre 2021, consultado el 15 septiembre 2022. URL: http://

journals.openedition.org/artelogie/9698; DOI: https://doi.org/10.4000/artelogie.9698

Este documento fue generado automáticamente el 15 septiembre 2022.

All rights reserved 


\title{
Rumberas matanceras. Un canto a la memoria, Roxana M. Coz Téstar Miami, Estados Unidos. Unos \& Otros Ediciones, 2020. 154 páginas.
}

\author{
Rosa Marquetti Torres
}

1 ¿Es la rumba un género eminentemente masculino? ¿Hay un legado femenino en la rumba cubana que va más allá de los hombres venerados hoy como rumberos famosos? ¿Por qué Matanzas, ciudad del norte de la isla mayor de Cuba, cercana a su capital, como punto originario de un fenómeno matriarcal en la música cubana? ¿Trascendencia social, vigencia o historia pasada? Son interrogantes que motivaron la investigación que sustenta este libro.

2 Rumberas matanceras. Un canto a la memoria, editado por Unos \& Otros Ediciones (Miami, USA. 2020), es el resultado del trabajo de grado con la que su autora Roxana M. Coz Testar concluyó sus estudios de Musicología en la Universidad de las Artes de Cuba. Al mismo tiempo, el primer texto investigativo que aborda a la mujer rumbera desde la perspectiva de su pertenencia histórica a una de las zonas que dieron origen a la rumba, como género músico-danzario de origen y carácter urbano: Matanzas, y sus barrios raigales de Simpson y La Marina. La autora investiga y enfoca el azaroso y secular recorrido de vida en el que supieron preservar en cantos y baile el legado de las fundadoras de dos clanes familiares de gran prestigio rumbero en la ciudad de Matanzas: las familias Calle y Mesa, la de la famosa rumbera Estanislá Luna, y su influencia dentro de las formaciones socioculturales espontáneas que han mantenido por más de cien años la vigencia de un género autóctono e identitario, como es la rumba. La autora considera un aporte significativo a su investigación “...poder demostrar el rastro de matrifocalidad presente en familias de rumberos...", valiéndose de exhaustivas pesquisas que prometían gran complejidad, habida cuenta de la racialidad implícita en los archivos del período colonial y principalmente, en la etapa de la esclavitud, en el siglo XIX. 
3 La reconstrucción de la genealogía de estas familias de origen africano permitió a la autora establecer los diferentes roles femeninos en la jerarquía rumbera y establecer los niveles de reconocimiento social que a lo largo de más de una centuria pudieron alcanzar, dentro de una sociedad marcada prejuicios de raza y clase social. La interseccionalidad de las figuras femeninas más prominentes y las dificultades que en consecuencia han debido asumir; la interacción con los líderes masculinos, y su propio y particular accionar en un ámbito históricamente patriarcal para demostrar paulatinamente lo indispensable no solo de su presencia, sino de la conquista gradual de un liderazgo, es explorado y demostrado por la autora en este libro.

4 La autora concede especial atención a la delimitación geográfica de los barrios rumberos donde se concentra una población de escasos recursos económicos, esencialmente trabajadora -de obreros, braceros portuarios y personal de servicio-, que también dan origen a formaciones socio-musicales que son decisivas en el asentamiento de la tradición y el desarrollo de la rumba matancera. Hace una inmersión en el entorno geográfico, hurga en el significado del solar, como célula socializadora y en gran medida originaria, el espacio donde habitan y surge los cantos y toques rumberos sin más instrumentos musicales que los objetos que circundan la vida diaria de sus moradores y que, en ocasiones, condicionan la performatividad, que luego trasciende ese marco para replicarse en la escena.

5 Con un carácter histórico y musicológico con énfasis en los procesos investigativos, estos temas son abordados en ocho capítulos o secciones en que se estructura el libro, antecedidos por tres secciones que la autora considera necesarias: Palabras de la autora, Introducción y ¿Qué se ha escrito de las rumberas? En ellas, sucesivamente, comparte con los lectores las motivaciones que la llevaron a esta investigación y las dificultades iniciales que debió enfrentar; los objetivos que se propone y las tesis a demostrar; y las publicaciones que le antecedieron en el enfoque del rol femenino en la rumba. En particular resulta encomiable el análisis del repertorio de rumbas originarias de los barrios matanceros, conservados por transmisión generacional en forma oral y que ahora, en algunos ejemplos, aparecen transcriptos musicalmente en este libro. "El repertorio de cantos funciona como canal transmisor de experiencias, procurando la continuidad de la memoria histórica, ya sea desde la práctica familiar o social de la rumba. El canto se constituye como reflejo de la preservación, adaptación y reelaboración de rasgos propios de la cultura musical cubana y promueve una nueva forma de articular un discurso musical $y$ performativo en el espacio matancero de la rumba." Esta afirmación evidencia la preocupación de la autora concretada en uno de sus objetivos: demostrar la vigencia de estas tradiciones a través de la continuidad en las actuales generaciones de rumberas matanceras, empoderadas en nuevos espacios de expresión performativa y composicional, en una sociedad más empática e integradora en el reconocimiento de la rumba como fenómeno socio-musical. Las nuevas rumberas matanceras reivindican el rol femenino en la rumba y las tradiciones de su ciudad y región: "En la memoria de las rumberas contemporáneas queda el recuerdo que a su paso dejaron las generaciones anteriores: huellas de la memoria oral plasmadas en los cantos transmitidos, en el movimiento aprendido y recreado siempre en el baile. Las mujeres de hoy disfrutan la rumba con la misma intensidad de sus abuelas, pero han ganado dentro de ella el derecho a incidir en su desarrollo. Ahora dirigen agrupaciones encauzan proyectos, deciden cómo hacer de ella un discurso artístico genuino. Son sujetos conscientes de la necesidad de preservar la tradición rumbera: están comprometidas con el cuidado de ese patrimonio artístico." 
6 Como sección final, los anexos incluyen imágenes facsimilares de importantes y antiguos documentos que muestran hechos trascendentes en la historia de los antecedentes de la rumba, que van desde la demonización del uso de los tambores y de las manifestaciones musicales de esclavos y negros libres en la época colonial, hasta los documentos de identidad de las matriarcas principales entre las rumberas matanceras. Una sección iconográfica y la bibliografía completan los anexos.

7 Rumberas matanceras. Un canto a la memoria, se suma a los textos musicológicos e histórico-musicales sobre un género tan trascendente como la rumba, parte indisoluble del patrimonio inmaterial de la cultura cubana y como tal, refrendada por la UNESCO. Se distingue, no obstante, por la mirada hacia un fenómeno privativo de la región matancera, más allá de la ciudad que se extiende al ámbito de la provincia del mismo nombre, que involucra de manera destacada a la mujer, en nombres de rumberas como Estanislá Luna, Andrea Baró, y otras hicieron leyenda. El abordaje de este tema desde el feminismo y la percepción musicológica subrayan la singularidad del texto de Roxana M. Coz Testar y animan a recomendar a la autora la continuidad en las investigaciones y búsquedas al interior de un ámbito delimitado geográficamente en que surge un fenómeno cultural comunitario que, si bien tiene nexos con otras zonas del archipiélago cubano, preserva en la provincia de Matanzas su singularidad y continuidad a través del tiempo. 